\title{
Effect of an inhaled neutral endopeptidase inhibitor, phosphoramidon, on baseline airway calibre and bronchial responsiveness to bradykinin in asthma
}

Nunzio Crimi, Riccardo Polosa, Giuseppe Pulvirenti, Salvatore Magrì, Giuseppe Santonocito, Gaetano Prosperini, Claudio Mastruzzo, Antonino Mistretta

Istituto Malattie Apparato

Respiratorio,

Università di Catania,

Via Passo Gravina 187,

95125 Catania, Italy

N Crimi

R Polosa

G Pulvirenti

$S$ Magrì

G Santonocito

G Prosperini

C Mastruzzo

A Mistretta

Reprint requests to: Dr N Crimi.

Received 15 July 1994 Returned to authors 12 October 1994

Revised version received 24 November 1994 Accepted for publication 19 January 1995

\section{Abstract}

Background - Bradykinin is a potent vasoactive peptide which has been proposed as an important inflammatory mediator in asthma since it provokes potent bronchoconstriction in asthmatic subjects. Little is known at present about the potential role of lung peptidases in modulating bradykinin-induced airway dysfunction in vivo in man. The change in bronchial reactivity to bradykinin was therefore investigated after treatment with inhaled phosphoramidon, a potent neutral endopeptidase (NEP) inhibitor, in a double blind, placebo controlled, randomised study of 10 asthmatic subjects.

Methods - Subjects attended on six separate occasions at the same time of day during which concentration-response studies with inhaled bradykinin and histamine were carried out, without treatment and after each test drug. Subjects received nebulised phosphoramidon sodium salt $\left(10^{-5} \mathrm{M}, 3 \mathrm{ml}\right)$ or matched placebo for 5-7 minutes using an Inspiron Mini-neb nebuliser 5 minutes before the bronchoprovocation test with bradykinin or histamine. Agonists were administered in increasing concentrations as an aerosol generated from a starting volume of $3 \mathrm{ml}$ in a nebuliser driven by compressed air at $81 / \mathrm{min}$. Changes in airway calibre were measured as forced expiratory volume in one second $\left(F E V_{1}\right)$ and responsiveness as the provocative concentration causing a $20 \%$ fall in $\mathrm{FEV}_{1}\left(\mathrm{PC}_{20}\right)$.

Results - Phosphoramidon administration caused a transient fall in $\mathrm{FEV}_{1}$ from baseline, $F_{E V}$ values decreasing $6 \cdot 3 \%$ and $5 \cdot 3 \%$ on the bradykinin and histamine study days, respectively. When compared with placebo, phosphoramidon elicited a small enhancement of the airways response to bradykinin, the geometric mean $\mathbf{P C}_{20}$ value (range) decreasing from $0 \cdot 281$ $(0 \cdot 015-5 \cdot 575)$ to $0 \cdot 136(0 \cdot 006-2 \cdot 061) \mathrm{mg} / \mathrm{ml}$. In contrast, NEP blockade failed to alter the airways response to a subsequent inhalation with histamine, the geometric mean (range) $\mathbf{P C}_{20}$ histamine value of 1.65 $(0 \cdot 17-10 \cdot 52) \mathrm{mg} / \mathrm{ml}$ after placebo being no different from that of $1 \cdot 58(0 \cdot 09-15 \cdot 21) \mathrm{mg} /$ $\mathrm{ml}$ obtained after phosphoramidon.

Conclusions - The small increase in bron- chial reactivity to bradykinin after phosphoramidon exposure suggests that endogenous airway NEP may play a modulatory role in the airways response to inflammatory peptides in human asthma.

(Thorax 1995;50:505-510)

Keywords: asthma, bronchospasm, bradykinin, histamine, phosphoramidon.

Neutral endopeptidase (NEP, also known as neutral metalloendopeptidase, enkephalinase, CALLA, or E.C. 3.4.24.11) is a membranebound enzyme that cleaves a large variety of peptidic hormones including enkephalins, tachykinins (such as neurokinin $A$ and substance $P$ ), and kinins (such as bradykinin and kallidin). ${ }^{1}$ Although NEP is widely distributed in the body, the highest activity is normally found in the lung, particularly at the level of airway epithelium and smooth muscle. ${ }^{2}$ A major potential physiological role for NEP in human airways has recently been proposed. Its enzymatic activity may exert a "braking effect" on airway smooth muscle contraction by inactivating peptidic hormones released under inflammatory conditions including asthma. ${ }^{13}$

Kinins in general, and bradykinin in particular, are naturally occurring vasoactive peptides formed de novo in body fluids and tissues during inflammatory processes which have also been implicated in the pathophysiology of bronchial asthma and related allergic disorders. ${ }^{4}$ Bradykinin is generated from circulating kininogens through proteolytic cleavage by a variety of enzymes, the most important of which are tissue and plasma kallikreins. ${ }^{5}$ Evidence that kinin generation may be increased under conditions which prevail in areas of allergic inflammation in the airways has recently been obtained from studies in asthmatic ${ }^{6-8}$ and rhinitic subjects. ${ }^{910}$ In addition, bradykinin is reported to possess many pharmacological properties pertinent to the pathogenesis of asthma, including vasodilatation and increased microvascular leakage, ${ }^{1112}$ bronchoconstriction, ${ }^{1314}$ activation of $\mathrm{C}$ fibre nociceptive sensory nerve endings, ${ }^{15} 16$ and induction of non-specific bronchial hyperresponsiveness in animals. ${ }^{17}$

The effector functions of bradykinin on the airways appear to be modulated by a variety of factors, including bradykinin hydrolysis by several peptidases. Little is known at present 
about the potential role of lung peptidases in modulating bradykinin-induced responses in vivo. There is increasing evidence that NEP may be the most important enzyme system involved in the degradation of bradykinin in the airways. ${ }^{1819}$ Although a number of animal studies have shown that the NEP inhibitor phosphoramidon $^{20}$ enhances the bronchoconstrictor effect of bradykinin both in vitro ${ }^{21}$ and in vivo, ${ }^{192223}$ the role of NEP in modulating airways responsiveness to bradykinin in man is not known.

The aim of the present study was therefore to investigate the effect of inhibiting endogenous NEP activity by inhaled phosphoramidon on bradykinin-induced bronchoconstriction and baseline airway calibre in asthmatic subjects. The strategy was based on the assumption that, if bradykinin is inactivated by NEP in the airways, then the selective enzyme inhibitor phosphoramidon should potentiate the airways responsiveness to bradykinin. The effect of phosphoramidon on histamine-induced reactivity was also assessed to rule out possible non-specific effects of this agent on airways responsiveness.

\section{Methods}

SUBJECTS

Ten asthmatic subjects (eight women) with a mean (SE) age of $29.5(3.3)$ years referred to our hospital chest clinic with stable asthma as defined by the American Thoracic Society ${ }^{24}$ participated in the study (table 1). All subjects had a history of dyspnoea with wheezing or chest tightness upon exposure to airborne allergens and were non-smokers with positive skin prick tests ( $>2 \mathrm{~mm}$ weal response) to one or more of six common aeroallergens (Dermatophagoides pteronyssinus, Dermatophagoides farinae, wall pellitory grass, mixed grass pollens, cat fur, dog hair). At the beginning of the study all subjects were asymptomatic with a baseline $\mathrm{FEV}_{1}$ (forced expiratory volume in one second) $>80 \%$ of their predicted values. None had received oral corticosteroids, theophylline, antihistamines, or sodium cromoglycate within the preceding three weeks. Inhaled bronchodilators were discontinued for at least eight hours before each visit to the laboratory, although subjects were allowed to continue inhaled corticosteroids as usual. Five of the 10 subjects had been taking beclomethasone dipropionate by inhalation on a daily basis for at least six weeks (table 1). The study was approved by the ethical subcommittee of the Department of Respiratory Diseases (University of Catania), and all subjects gave their informed consent.

\section{BRONCHIAL PROVOCATION}

Airway calibre was recorded before and during the provocation as $\mathrm{FEV}_{1}$ using a dry wedge spirometer (Vitalograph, Buckinghamshire, UK), the better of the two consecutive measurements being recorded.

Histamine acid phosphate (Sigma Chemical Co, St Louis, USA) was dissolved in $0.9 \%$ sodium chloride to produce a stock solution of $16 \mathrm{mg} / \mathrm{ml}(52 \mathrm{mmol} / \mathrm{l})$. On each study day bradykinin triacetic acid (Sigma Chemical Co, St Louis, USA) was freshly prepared in 5\% ethanol with $0.9 \%$ sodium chloride to produce stock solutions of $8 \mathrm{mg} / \mathrm{ml}$. Each stock solution was then diluted with its respective diluent to produce a concentration range of $0.03-8 \mathrm{mg} /$ $\mathrm{ml}(0 \cdot 1-26 \mathrm{mmol} / \mathrm{l})$ for histamine and of $0.00375-4 \mathrm{mg} / \mathrm{ml} \quad(0.0035-3.77 \mathrm{mmol} / \mathrm{l})$ for $\overrightarrow{0}$ bradykinin. To avoid loss of bradykinin through peptide degradation and adherence to plastic surfaces, the stock solutions were stored at $4^{\circ} \mathrm{C}$ prior to use and bronchoprovocation was performed within 30 minutes of preparing the dilutions.

The solutions were administered as aerosols generated from a starting volume of $3 \mathrm{ml}$ in a disposable Inspiron Mini-nebuliser (CR Bard International, Sunderland, UK) driven by compressed air at $81 / \mathrm{min}$. Subjects inhaled the aerosolised solutions in five breaths from end tidal volume to full inspiratory capacity via a mouthpiece as described by Chai et al. ${ }^{25} \mathrm{Sub}-$ jects were trained to take three seconds to reach full inspiratory capacity.

\section{STUDY DESIGN}

The study consisted of three separate phases.

\section{Phase 1}

In the first phase subjects (nos 1-10) attended the laboratory on two separate occasions at least 48 hours apart to undertake concentration-

Table 1 Demographic details of subjects studied

\begin{tabular}{|c|c|c|c|c|c|c|}
\hline $\begin{array}{l}\text { Subject } \\
\text { no. }\end{array}$ & Sex & $\begin{array}{l}\text { Age } \\
\text { (years) }\end{array}$ & $\begin{array}{l}\text { Baseline FEV } \\
\text { (\% predicted) }\end{array}$ & Atopy & $\begin{array}{l}P C_{20} \text { histamine } \\
(\mathrm{mg} / \mathrm{ml})\end{array}$ & Regular medications \\
\hline $\begin{array}{r}1 \\
2 \\
3 \\
4 \\
5 \\
6 \\
7 \\
8 \\
9 \\
10\end{array}$ & $\begin{array}{l}F \\
F \\
F \\
F \\
M \\
F \\
F \\
F \\
F \\
M\end{array}$ & $\begin{array}{l}18 \\
29 \\
40 \\
41 \\
32 \\
28 \\
21 \\
23 \\
47 \\
16\end{array}$ & $\begin{array}{r}103 \\
107 \\
97 \\
89 \\
98 \\
95 \\
89 \\
101 \\
97 \\
123\end{array}$ & $\begin{array}{l}\text { D } \\
\text { D, W } \\
\text { W } \\
\text { W, G } \\
\text { W } \\
\text { D } \\
\text { W, G } \\
\text { D } \\
\text { W, G } \\
\text { W }\end{array}$ & $\begin{array}{r}0 \cdot 33 \\
1 \cdot 70 \\
3 \cdot 47 \\
2 \cdot 00 \\
4 \cdot 11 \\
0 \cdot 11 \\
1 \cdot 69 \\
0.98 \\
6.48 \\
11.90\end{array}$ & $\begin{array}{l}\text { S, BDP }(1500 \mu \mathrm{g}) \\
\text { S, } \\
\text { S, BDP }(1000 \mu \mathrm{g}) \\
\text { S } \\
\text { S } \\
\text { S, BDP }(2000 \mu \mathrm{g}) \\
\text { S, BDP }(1000 \mu \mathrm{g}) \\
\text { S } \\
\text { S, BDP }(1000 \mu \mathrm{g}) \\
\text { S, SCG }\end{array}$ \\
\hline \multicolumn{2}{|c|}{ Mean (SE) } & $29 \cdot 5(3 \cdot 3)$ & $99.9(3 \cdot 1)$ & & $1 \cdot 72 *(0 \cdot 11-$ & \\
\hline
\end{tabular}


response studies with inhaled histamine and bradykinin in the absence of any drug treatment. On the first occasion, after a 15 minute rest, three baseline measurements of $\mathrm{FEV}_{1}$ were made at intervals of three minutes followed by inhalation of the corresponding diluent solution and further $\mathrm{FEV}_{1}$ measurements repeated at one and three minutes. Provided $\mathrm{FEV}_{1}$ had not fallen by $>10 \%$ of the baseline value, a histamine concentration-response study was carried out. After administration of each histamine concentration $\mathrm{FEV}_{1}$ was measured at one and three minutes. Increasing doubling concentrations of histamine were inhaled at five minute intervals until $\mathrm{FEV}_{1}$ had fallen by $>20 \%$ of the post-saline baseline value and the corresponding $\mathrm{PC}_{20} \mathrm{FEV}_{1}$ values derived. On the second occasion a bronchial provocation test with inhaled bradykinin was undertaken according to a previously described protocol. ${ }^{14}$ In brief, increasing concentrations of bradykinin were inhaled at approximately five minute intervals until $\mathrm{FEV}_{1}$ had fallen by $>20 \%$ of the post-diluent value and the corresponding $\mathrm{PC}_{20} \mathrm{FEV}_{1}$ values derived.

\section{Phase 2}

In the second phase subjects (nos 1-10) attended the laboratory on two separate visits, at least five days apart, to undertake concentration-response studies with inhaled bradykinin after receiving nebulised phosphoramidon (Sigma Chemical Co, St Louis, USA) or matched nebulised vehicle placebo administered double blind and in random order five minutes prior to challenge. Both the active and placebo solutions were freshly prepared by an independent investigator on the basis of a randomised code and then returned to the conducting physician to administer to the attending subject. On each occasion, after a 15 minute rest, three baseline measurements of $\mathrm{FEV}_{1}$ were made at intervals of three minutes followed by inhalation of nebulised phosphoramidon $\left(10^{-5} \mathrm{M}, 3 \mathrm{ml}\right)$ or nebulised vehicle placebo consisting of $0.9 \%$ sodium chloride adjusted to the same $\mathrm{pH}$ and tonicity as the phosphoramidon. The aerosol solutions were generated from a starting volume of $3.0 \mathrm{ml}$ in an Inspiron mini-nebuliser driven by compressed air at $8 \mathrm{l} / \mathrm{min}$ and inhaled to dryness by deep tidal breathing over a 5-7 minute time period. The same nebuliser was used for all studies on all subjects. Further $\mathrm{FEV}_{1}$ measurements were repeated two and five minutes after drug/placebo inhalation and bradykinin challenge was carried out in a similar manner to that described in phase 1 .
Phase 3

The final phase of the study was carried out to determine the specificity of the effect of the drug tested on subsequent non-specific contractile stimuli. Eight subjects (nos 1, 2, 3, 6, $7,8,9$, and 10) attended the laboratory on two further visits, at least five days apart, to undertake concentration-response studies with inhaled histamine after receiving nebulised phosphoramidon $\left(10^{-5} \mathrm{M}, 3 \mathrm{ml}\right)$ or matched nebulised vehicle placebo administered in an identical fashion to that described in phase 2 .

\section{DATA ANALYSIS}

Figures are presented as mean (SE) unless otherwise stated, with a level of significance of $p<0.05$. Pre-treatment and post-treatment baseline values of $\mathrm{FEV}_{1}$ prior to bronchial challenges were compared between and within study days by two-factor analysis of variance (ANOVA) followed by Neuman-Keuls test, where appropriate.

Concentration-response curves were constructed by plotting the percentage change in $\mathrm{FEV}_{1}$ from the post-diluent baseline value against the cumulative concentration of the agonist administered on a logarithmic scale and the concentration of agonist required to produce a $20 \%$ fall in $\mathrm{FEV}_{1}$ from the postdiluent baseline value $\left(\mathrm{PC}_{20} \mathrm{FEV}_{1}\right)$ determined by linear interpolation.

The repeatability of the bradykinin challenge procedure was determined according to the method described by Altman and Bland. ${ }^{26}$

Values of $\mathrm{PC}_{20}$ bradykinin and histamine following treatment with phosphoramidon and placebo were logarithmically transformed to normalise their distribution and compared by the Student's $t$ test for paired data. Concentration ratios for the effect of phosphoramidon against bronchoprovocation with each agonist were calculated by dividing the $\mathrm{PC}_{20}$ value obtained after administration of active drug by that obtained after placebo and compared using the Wilcoxon signed rank test.

Any relationship was examined by least squares linear regression analysis.

\section{Results}

EFFECT OF INHALED PHOSPHORAMIDON ON AIRWAY CALIBRE

There was no significant difference in baseline values of $F E V_{1}$ between any of the study days (table 2). However, two minutes after administration of nebulised phosphoramidon $\mathrm{FEV}_{1}$ values were significantly lower than their predrug values, decreasing $6.3 \%$ and $5.3 \%$ from $3.12(0.23)$ to $2.93(0.22) 1(\mathrm{p}<0.01$;

Table 2 Effect of pretreatment with inhaled phosphoramidon and placebo on mean (SE) baseline FEV, values (litres) on bradykinin and histamine study days

\begin{tabular}{|c|c|c|c|c|c|c|c|c|c|c|}
\hline & $\begin{array}{l}\text { Pre- } \\
\text { placebo }\end{array}$ & $\begin{array}{l}\text { Post-placebo } \\
2^{\prime}\end{array}$ & $\Delta \% 2^{\prime}$ & $\begin{array}{l}\text { Post-placebo } \\
5^{\prime}\end{array}$ & $\Delta \% 5^{\prime}$ & Pre-phosphoramidon & $\begin{array}{l}\text { Post-phosphoramidon } \\
2^{\prime}\end{array}$ & $\Delta \% 2^{\prime}$ & $\begin{array}{l}\text { Post-phosphoramidon } \\
5^{\prime}\end{array}$ & $\Delta \% 5^{\prime}$ \\
\hline Bradykinin & $\begin{array}{c}3 \cdot 24 \\
(0 \cdot 26)\end{array}$ & $\begin{array}{c}3 \cdot 14 \\
(0 \cdot 24)\end{array}$ & $2 \cdot 9 \%$ & $\begin{array}{c}3 \cdot 15 \\
(0 \cdot 24)\end{array}$ & $2 \cdot 7 \%$ & $\begin{array}{c}3 \cdot 12 \\
(0 \cdot 23)\end{array}$ & $\begin{array}{c}2 \cdot 93 \\
(0 \cdot 22)\end{array}$ & $6 \cdot 3 \%$ & $\begin{array}{c}3 \cdot 08 \\
(0 \cdot 24)\end{array}$ & $1 \cdot 6 \%$ \\
\hline Histamine & $\begin{array}{c}3 \cdot 26 \\
(0 \cdot 28)\end{array}$ & $\begin{array}{c}3 \cdot 22 \\
(0 \cdot 30)\end{array}$ & $1 \cdot 3 \%$ & $\begin{array}{c}3 \cdot 23 \\
(0 \cdot 29)\end{array}$ & $1 \cdot 1 \%$ & $\begin{array}{c}3 \cdot 28 \\
(0 \cdot 30)\end{array}$ & $\begin{array}{c}3 \cdot 11 \\
(0 \cdot 30)\end{array}$ & $5 \cdot 3 \%$ & $\begin{array}{c}3.23 \\
(0 \cdot 31)\end{array}$ & $1.9 \%$ \\
\hline
\end{tabular}


Patient 1

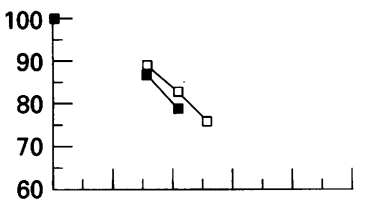

Patient 5

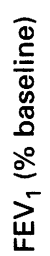

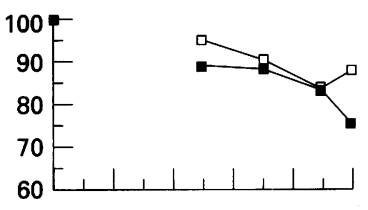

Patient 9

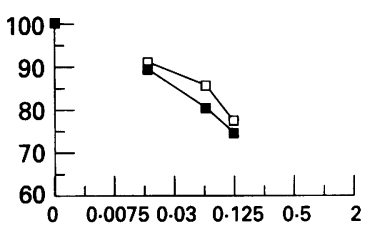

Patient 2

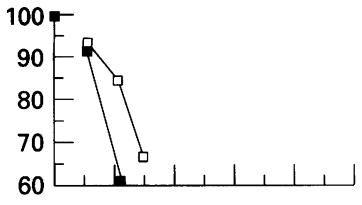

Patient 6

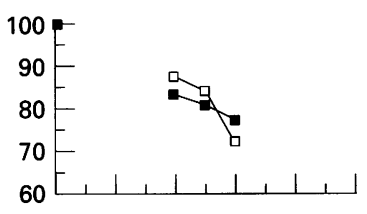

Patient 10

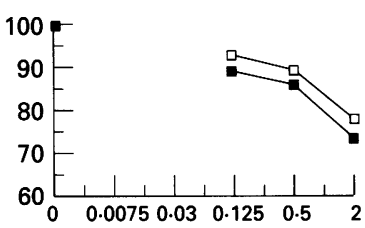

Patient 3

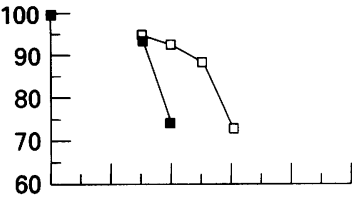

Patient 7

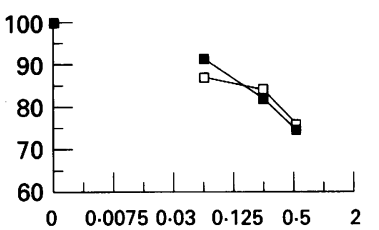

Patient 4

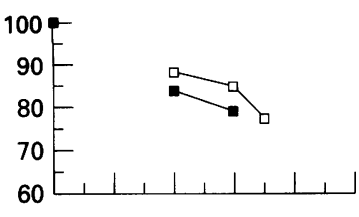

Patient 8

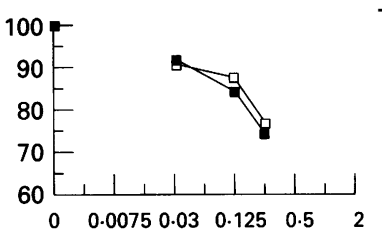

Cumulative concentration of bradykinin $(\mathrm{mg} / \mathrm{ml})$

Figure 1 Effect of placebo ( $\square$ ) and phosphoramidon ( $\square$ ) on the concentration-related falls in FEV produced by inhaled bradykinin in 10 subjects with asthma.

Patient 1

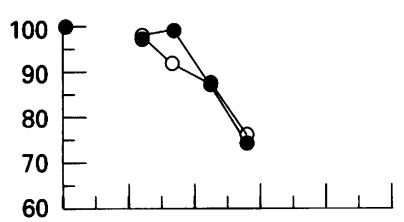

Patient 7

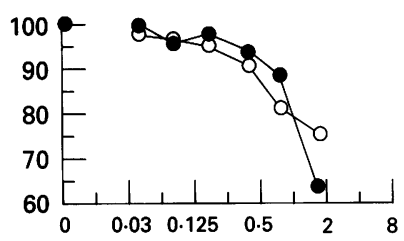

Patient 2

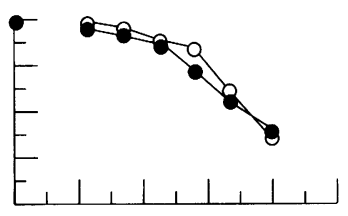

Patient 8

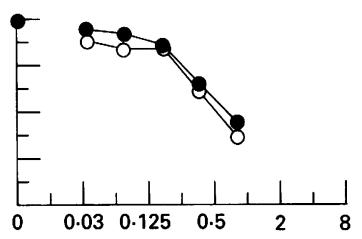

Patient 3

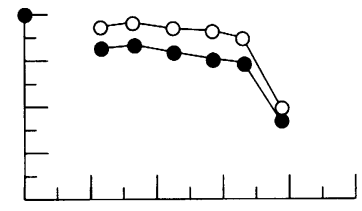

Patient 9

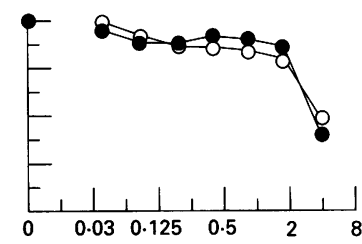

Patient 6

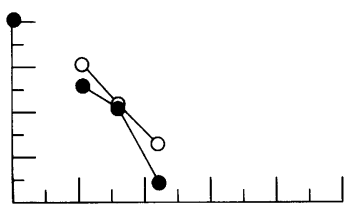

Patient 10

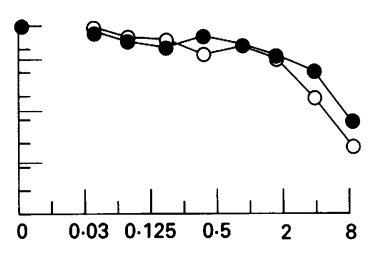

Cumulative concentration of histamine $(\mathrm{mg} / \mathrm{ml})$

Figure 2 Effect of placebo $(O)$ and phosphoramidon (O) on the concentration-related falls in FEV, produced by inhaled histamine in eight subjects with astham.

$\mathrm{n}=10)$ and from $3 \cdot 28(0 \cdot 30)$ to $3 \cdot 11(0 \cdot 30) \mathrm{l}$ $(\mathrm{p}<0.05 ; \mathrm{n}=8)$ on the bradykinin and histamine study days, respectively (table 2 ). $\mathrm{FEV}_{1}$ values measured five minutes after nebulised phosphoramidon was given were significantly higher than those measured at two minutes (table 2). In addition, the mean baseline values of $\mathrm{FEV}_{1}$ following administration of phosphoramidon were significantly $(p<0.05)$ lower than after placebo when compared at two minutes but not at five minutes (table 2). Phosphoramidon elicited a fall in $\mathrm{FEV}_{1}$ of $>5 \%$ from baseline in seven of the 10 subjects studied. No significant correlations could be established between the degree of fall in $\mathrm{FEV}_{1}$ induced by $\stackrel{2}{\circledR}$ phosphoramidon and the concentration ratio after the active drug or baseline $\mathrm{FEV}_{1}$ values 0 or baseline airways responsiveness to brady-을 kinin or histamine.

EFFECT OF INHALED PHOSPHORAMIDON ON CONCENTRATION-RESPONSE CURVE TO BRADYKININ

The challenge procedure with bradykinin in this group of patients was found to be repeatable, with a coefficient which was within $1 \cdot 1$ doubling dilutions (for nine of the 10 sub- 
jects to within a single doubling dilution). These findings were consistent with the repeatability data obtained in previous studies with bradykinin bronchoprovocation tests. ${ }^{1427}$ In phase 1 inhaled histamine and bradykinin produced concentration-related falls in $\mathrm{FEV}_{1}$. The geometric mean (range) of $\mathrm{PC}_{20}$ values obtained were $1.72(0.11-11.9)$ and 0.226 $(0.014-4.467) \mathrm{mg} / \mathrm{ml}$ for histamine and bradykinin, respectively. In phase 2 inhaled phosphoramidon had a small but significant enhancing effect against the fall in $\mathrm{FEV}_{1}$ produced by bradykinin (fig 1), the geometric mean (range) $\mathrm{PC}_{20}$ values decreasing $2 \cdot 1$-fold from $0.281(0.015-5.575) \mathrm{mg} / \mathrm{ml}$ after placebo to $0.136(0.006-2.061) \mathrm{mg} / \mathrm{ml}$ after phosphoramidon $(\mathrm{p}<0.01)$. No correlation could be found between the degree of fall in $\mathrm{FEV}_{1}$ values and the potentiation of airways response to bradykinin following exposure to phosphoramidon.

\section{EFFECT OF INHALED PHOSPHORAMIDON ON CONCENTRATION-RESPONSE CURVE TO HISTAMINE}

In phase 3 the same dose of inhaled phosphoramidon failed to alter the airways response to a subsequent inhalation with histamine (fig 2), despite being effective in inducing significant changes in baseline airway calibre (table 2). The geometric mean (range) $\mathrm{PC}_{20}$ value of $1.65(0 \cdot 17-10.52) \mathrm{mg} / \mathrm{ml}$ after placebo was not significantly different from that of 1.58 $(0 \cdot 09-15 \cdot 21) \mathrm{mg} / \mathrm{ml}$ obtained after phosphoramidon.

\section{Discussion}

In asthmatic subjects inhibition of NEP by inhaled phosphoramidon elicits a small but significant enhancement to the bronchospastic response provoked by bradykinin, without changing the response to histamine. These findings support the view that a functional NEP system is present and specifically limits the effects of the contractile oligopeptide bradykinin in asthmatic airways in vivo. In addition, it was interesting to note that exposure to phosphoramidon elicited a small but significant time-dependent fall in $\mathrm{FEV}_{1}$ in the subjects studied.

In contrast to previously published work with inhaled NEP inhibitors, ${ }^{28-30}$ the present study shows changes in airway calibre following NEP blockade in man. The reasons for this discrepancy are not clear. Higher doses of this drug could have been followed by a more significant change in baseline airway calibre. Indeed, compared with previous work, ${ }^{29}{ }^{30}$ the total dose of phosphoramidon used in the present investigation was considerably higher, thus explaining the reported $6 \%$ change from baseline $\mathrm{FEV}_{1}$. Timing of $\mathrm{FEV}_{1}$ recording after drug exposure also might been crucial as the fall in baseline $\mathrm{FEV}_{1}$ values was only significant at two minutes, thus justifying the lack of change from baseline $\mathrm{FEV}_{1}$ at 10 minutes after NEP inhibition described in two recent investigations. ${ }^{2930}$ The immediate bronchoconstriction seen after phosphoramidon may be the result of an irritant effect of the drug, but we cannot exclude other possibilities. Comparison between the subjects studied and those from previous studies showed no difference in their characteristics except for the use of inhaled corticosteroids. Phosphoramidon elicited a significant fall in $\mathrm{FEV}_{1}$ only in the subjects taking inhaled steroids. The reason for this is not known, but we are currently exploring this finding in a series of controlled studies. As it has been shown that increased NEP activity is present in glucocorticoid-treated human epithelial cells, ${ }^{31}$ it is possible that inhaled steroids could increase NEP activity within the airways to such a level that the addition of a specific NEP inhibitor (phosphoramidon) might reveal a basal peptidergic tone.

We have also shown the functional importance of endogenous NEP in modulating reactivity of the airways to exogenously administered bradykinin. That NEP inhibition has a specific effect on airways responsiveness to bradykinin is demonstrated by the lack of change in histamine reactivity after phosphoramidon. The present data are in line with the evidence provided by several authors on the potentiation of bradykinin-induced airways responses following NEP blockade in animal studies. ${ }^{1921-23}$

Although the bradykinin challenge was repeatable to within one doubling dilution of agonist in eight out of nine subjects, it must be pointed out that the $2 \cdot 1$-fold potentiation of bradykinin responsiveness after phosphoramidon exposure should be interpreted with caution. However, the degree of potentiation shown in the present study with NEP inhibition is similar to that reported by $\mathrm{us}^{29}$ and others ${ }^{30}$ against the airway effect of neurokinin $A$ in asthma. Thus, despite the fact that phosphoramidon is a potent inhibitor of NEP, its effect on bradykinin-induced airway changes may be negligible because of the hydrolysis of bradykinin by other lung peptidases including angiotensin converting enzyme (ACE, kininase 2) and carboxypeptidase $\mathrm{N}$ and $M .{ }^{45}$ This emphasises the importance of alternative enzymatic pathways in the modulation of kinin responses in man.

NEP degrades a variety of peptides including bradykinin by cleaving the $\mathrm{Pro}^{7}-\mathrm{Phe}^{8}$ bond, thereby releasing inactive peptidic fragments. ${ }^{18}$ Because of its localisation on the plasma membrane, NEP may be involved in the local control of peptide hormone activity by inactivating or altering the receptor specificity of peptides at their site of action. ${ }^{1}$ This view has been substantiated by a series of clinical investigations in normal ${ }^{28}$ and asthmatic subjects ${ }^{29} 30$ in which potentiation of the bronchoconstriction induced by the neuropeptide neurokinin $\mathrm{A}$ was demonstrated following NEP blockade.

The mechanism of bradykinin-induced bronchoconstriction in asthma is unknown but release of spasmogenic tachykinins is a possibility. ${ }^{4}$ The enhancing effect of phosphoramidon on bradykinin-induced bronchoconstriction might therefore have been the result of NEP directly contributing to brady- 
kinin metabolism or by metabolising endogenous tachykinins released by bradykinin. Indeed, we and others have shown that NEP inhibition significantly enhances the airways response to inhaled neurokinin $\mathrm{A}$ in healthy and asthmatic subjects. ${ }^{28-30}$

In health, kinins usually exist in the circulating blood at very low concentrations as a result of the balance between their production and inactivation by plasma and tissue enzymes. In various respiratory diseases kinin levels may be raised and may dramatically impair airway function. Whilst inhalation of bradykinin aerosols was shown to have no detectable effect on airway calibre in normal subjects, when administered to patients with asthma it resulted in a concentration-related bronchoconstriction. ${ }^{14}$ Part of this discrepancy may be related to the loss of activity of the endogenous peptide degrading enzyme, NEP, which seems to occur in those conditions characterised by shedding of the airway epithelium - for example, acture viral infections, exposure to inhaled irritants, or bronchial asthma. ${ }^{3}$ Two recent studies have shown that mechanical removal of the respiratory epithelium increases the reactivity of the underlying smooth muscle of intact guinea pig trachea to the constrictor effects of several peptidic hormones including tachykinins and bradykinin. ${ }^{2132}$ As the enzyme NEP $24 \cdot 11$ is strongly expressed on airway epithelial cells ${ }^{2}$ and is very important in the degradation of tachykinins and kinins, ${ }^{1}$ removal of the airway epithelium may explain the enhanced constrictor effect of bradykinin. Shedding of the epithelium is commonly observed in the airways of asthmatic subjects ${ }^{334}$ and this could contribute to the increased airways response to inhaled kinins in asthma.

In conclusion, this is the first demonstration of the potential physiological importance of NEP activity in regulating airways responsiveness to bradykinin in asthma in vivo. The study shows that exogenously administered bradykinin may be a suitable substrate for NEP in asthmatic airways, and that phosphoramidon given by inhalation is effective, not only in enhancing the bronchoconstrictor response of exogenously administered bradykinin, but also in reducing the airway calibre in most of our subjects, thus suggesting that a basal endogenous peptidergic tone is functionally active in asthmatic airways. We speculate that diseases or therapies that decrease endogenous pulmonary neutral endopeptidase may underline the importance of such enzymatic systems in the control of kinininduced changes in airway function.

1 Borson DB. Roles of neutral endopeptidase in airways. $A m$ f Physiol (Lung Cell Mol Physiol 4) 1991;260:L212-25.

2 Johnson AR, Ashton J, Schulz WW, Erdos EG. Neutral metalloendopeptidase in human lung tiss

3 Nadel JA and Borson DB. Modulation of neurogenic inflammation by neutral endopeptidase. Am Rev Respir Dis 1991;143:533-6.

4 Polosa R. Role of the kinin-kallikrein pathway in allergic diseases. Allergy 1993;48:217-25.

5 Regoli D, Barabe J. Pharmacology of bradykinin and related peptides. Pharmacol Rev 1980;31:1-46.

6 Christiansen SC, Proud D, Cochrane CG. Detection of tissue kallikrein in the bronchoalveolar lavage fluid of asthmatic subjects. $\mathcal{F}$ Clin Invest 1987;75:188-97.

7 Christiansen SC, Proud D, Sarnoff RB, Juergens U,
Cochrane CG, Zuraw BL. Elevation of tissue kallikrein and kinin in the airways of asthmatic subjects after endobronchial allergen challenge. Am Rev Respir Dis 1992;145:900-5.

8 Liu MC, Hubbard WC, Proud D, Stealey BA, Galli SJ, Kagey-Sobotka A, et al. Immediate and late inflammatory responses to ragweed antigen challenge of the peripheral airways in allergic asthmatics. Cellular, mediator and per-

9 Proud D, Togias A, Naclerio RM, Crush SA, Norman PS, Lichtenstein LM. Kinins are generated in vivo following nasal airway challenge of allergic individuals with allergen. $\mathcal{7}$ Clin Invest 1983;72:1678-85.

10 Naclerio RM, Proud D, Togias AG, Adkinson Jr FN, Meyers DA, Kagey-Sobotka A, et al. Inflammatory mediators in late antigen-induced rhinitis. $N$ Engl $\mathcal{F}$ Med 1985;313: 65-70.

11 Corfield DR, Webber SE, Hanafi Z, Widdicombe JG. The actions of bradykinin and lys-bradykinin on tracheal blood flow and smooth muscle in anaesthetized sheep. Pulm Pharmacol 1991;4:85-90

12 Rajakulasingam K, Polosa R, Lau LCK, Church MK, Holgate ST, Howarth PH. Nasal effects of bradykinin and capsaicin: influence on plasma protein leakage and role of sensory neurons. F Appl Physiol 1992;72:1418-24.

13 Fuller RW, Dixon CMS, Cuss FMC, Barnes PJ. Bradykinininduced bronchoconstriction in humans. Mode of action. Am Rev Respir Dis 1987;135:176-80.

14 Polosa R, Holgate ST. Comparative airway responses to $G$ inhaled bradykinin, kallidin and $\left[\right.$ desArg $\left.^{9}\right]$-bradykinin in of normal and asthmatic subjects. Am Rev Respir Dis 1990; or 142:1367-71.

15 Kaufman MP, Coleridge HM, Coleridge JCG, Baker DG. or Bradykinin stimulates afferent vagal C-fibres in intra- 0 pulmonary airways in dogs. F Appl Physiol 1980;48: 511-7.

16 Inoue H, Koto H, Takata S, Aizawa H, Ikeda T. Excitatory role of axon reflex in bradykinin-induced contraction of guinea-pig tracheal smooth muscle. Am Rev Respir Dis guinea-pig tracheal

17 Soler M, Sielczak M, Abraham WM. A bradykinin antagonist blocks antigen-induced airway hyper- of responsiveness and inflammation in sheep. Pulm Pharmacol 1990;3:9-15.

18 Matsas R, Kenny AJ, Turner AJ. The metabolism of neuropeptides. The hydrolysis of peptides, including enkephalins, tachykinins and their analogues, by endopeptidase-24.11. Biochem f 1984;223:433-40.

19 Dusser DJ, Nadel JA, Sekizawa K, Graf PD, Borson DB. I Neutral endopeptidase and angiotensin converting enzyme inhibitors potentiate kinin-induced contraction of ferret $\vec{O}$ trachea. F Pharmacol Exp Ther 1988;244:531-6.

20 Hudgin RL, Charleson SE, Zimmerman M, Mumford R, Wood PL. Enkephalinase: selective peptide inhibitors. Life Sci 1981;29:2593-601.

21 Frossard N, Stretton CD, Barnes PJ. Modulation of bradykinin responses in airway smooth muscle by epithelial enzymes. Agents Actions 1990;31:204-9.

22 Ichinose M, Barnes PJ. The effect of peptidase inhibitors on bradykinin-induced bronchoconstriction in guinea-pigs in vivo. Br f Pharmacol 1990;101:77-80.

23 Chodimella V, Skidgel RA, Krowiak EJ, Murlas CG. Lung peptidases, including carboxypeptidase, modulate airway reactivity to intravenous bradykinin. Am Rev Respir Dis 1991;144:869-74.

24 American Thoracic Society. Standards for the diagnosis and 응 care of patients with COPD and asthma. Am Rev Respir Dis 1987;136:225-44.

25 Chai H, Farr RS, Froehlich LA, Mathison DA, McLean 을 $\mathrm{JA}$, et al. Standardization of bronchial inhalation challenge procedures. F Allergy Clin Immunol 1975;56:323-7.

26 Altman DG, Bland JH. Statistical methods for assessing agreement between two methods of clinical measurement. Lancet 1986;i:307-10.

27 Polosa R, Lai CKW, Robinson C, Holgate ST. The influence $\omega$ of cyclooxygenase inhibition on the loss of bronchoconstrictor response to repeated bradykinin challenge in asthma. Eur Respir f 1990;3:914-21.

28 Cheung D, Bel EH, Den Hartigh J, Dijkman JH, Sterk PJ. \& The effect of an inhaled neutral endopeptidase inhibitor, thiorphan, on airway responses to neurokinin A in normal humans in vivo. Am Rev Respir Dis 1992;145:1275-80.

29 Crimi N, Palermo F, Oliveri R, Polosa R, Magri S, Mistretta $\frac{O}{\mathbb{D}}$ A. Inhibition of neutral endopeptidase potentiates bron- $\Omega$ choconstriction induced by neurokinin $A$ in asthmatic $\mathbb{D}$ patients. Clin Exp Allergy 1994;24:115-20.

30 Cheung D, Timmers MC, Zwinderman AH, den Hartigh J, Dijkman JH, Sterk PJ. Neutral endopeptidase activity J, Dijkman JH, Sterk PJ. Neutral endopeptidase activity and airway hyperresponsiveness to neurokinin A in asthmatic subjects in vivo. Am Rev Respir Dis 1993;148:1467-

31 Borson DB, Gruenert DC. Glucocorticoids induce NEP inç transformed human tracheal epithelial cells. Am $\mathcal{f}$ Physiol (Lung Cell Mol Physiol 4) 1991;260:L83-9.

32 Frossard N, Rhoden KJ, Barnes PJ. Influence on guinea pig airway responses to tachykinins: role of endopeptidase and ciclooxygenase. $\mathcal{F}$ Pharmacol Exp Ther 1989;248:2928 .

33 Laitinen LA, Heino M, Laitinen A, Kava T, Haahtela T. Damage of the airways epithelium and bronchial reactivity in patients with asthma. Am Rev Respir Dis 1985;131: in patien.

34 Beasley R, Roche WE, Roberts JA, Holgate ST. Cellular events in the bronchi in mild asthma and after bronchia provocation. Am Rev Respir Dis 1989;139:806-17. 